


NAMES 


$$
\begin{aligned}
& E \\
& 98 \\
& N 2 \cup 5 \\
& \text { ANTHREP }
\end{aligned}
$$




\section{CIRCULAR OF INFORMATION REGARDING INDIAN POPULAR NAMES}

This bureau is in receipt of numerous requests for Indian names suitable for use by Camp Fire Girls and as camp names, and often for the translation into one or more of the many Indian languages of English expressions involving concepts wholly foreign to the Indian mode of thought. It is impossible for the bureau to devote the time and to meet the expense of special research incident to questions of this kind.

Appended is a selection of simplified Indian names designed to meet most of the requests received. The pronunciation of these names is as follows: $a$ as in father; $\hat{a}$ as in law; $e$ as $a$ in hate; $i$ as in machine; $a i$ as in aisle; $u$ as in rule. Short vowels are indicated in the customary manner ( $\breve{a}, \breve{e}, \breve{1}, \breve{o}, \breve{u})$; $\tilde{n}$ is nasalized, as in drink. The consonants are as in English.

\section{PERSONAL NAMES}

\section{DAKOTA (SIOUX)}

Chúmani_....... Dewdrops.

Chañtéyukañ_... Benevolent.

Chápa_.......... Beaver.

Chañtésuta_..... To be firm of heart.

Akikta One who works with determination.

Machá_._._._. The aurora.

Kimímela_....... The butterfly.

Tañkáku_....... Her younger sister.

Wózhupiwi_...... The planting moon (May).

Wóksapiwi The harvest moon (August).

Wakpála_....... Streamlet; little stream.

Wíshtecha_....... Modest.

Wakíchoñze -.... A leader.
Wañyécha_....... Firefly.

Wicháka_....... To be true.

Wa_.......... Snow.

Zitkála_.......... Little bird.

Zóñta _......... Trustworthy.

Wakápa_......... To excel.

Wápika_........ Skillful.

Wakíñyela_....... Dove.

Wóape_......... Hope.

Wówashi_....... A worker.

Mahpíyato_....... Blue cloud.

Winóna _. . _..... First-born daughter.

Wiyushkin _....... Harmonious.

Nahimana_._. . . Mystic.

Wichaka_....... Loyal.

Wiyapka_....... Radiant.

Washte_........ [it is] Beautiful.

\section{OMAHA}

Mítena__._._. The coming moon.
Mígina_._._... The returning
moon.
Míhewi____._. Sun woman.
Táini__._._._. The coming new
moon.

Tadéwi

Táigi

Weushi

Urika
Wind woman.

The returning new moon.

Helpful to everybody.

Useful to all. 
OSAGE

Iniabi_....... Refers to the sun,
on which all life
depends.

Mína _......... Elder sister.

Wíhe_.......... Younger sister.

Cola_........... Friend.

Watóge_._. _... Athlete.

Washóshe _...... Warrior.

Giwinke_....... Faithful.

Wazhin tunga_... Courage.

\section{$\operatorname{coos}$}

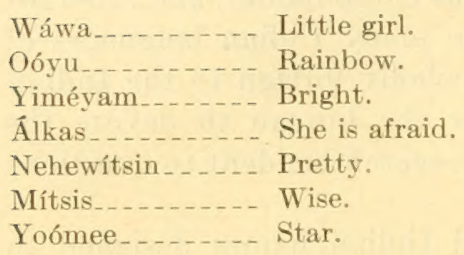

Aléshanee.

Towáyam

Heeneékis

Tkális

Háyoohaina
She plays all the time.

Beloved by all; lovable.

Equal to any.

Sun.

She is very active.

\section{BLACKFOOT}

Kokatosi_...... Star.

Nituna _......... My daughter.

Aponi........... Butterfly.

Kiniks_.......... Rosebud.

\section{DELAWARE}

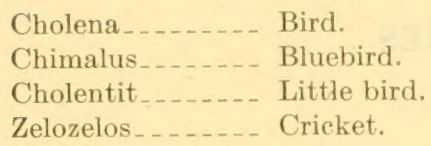

Woatawes _....... Flower.

Minal_.......... Fruit.

Tankho_........ Small.

\section{CHEYENNE}

Ístas_........... Snow.

Otókson_........ Little stars.

Viho _........... Chief.

Woiviho _........ Cloud chief.

Ioviano.......... Yellow hawk.

Nakashgonam_... My child.

Hoimani_...... Lawmaker.

Ihikona _. _. . . . . Industrious worker.

\section{CHEROKEE}

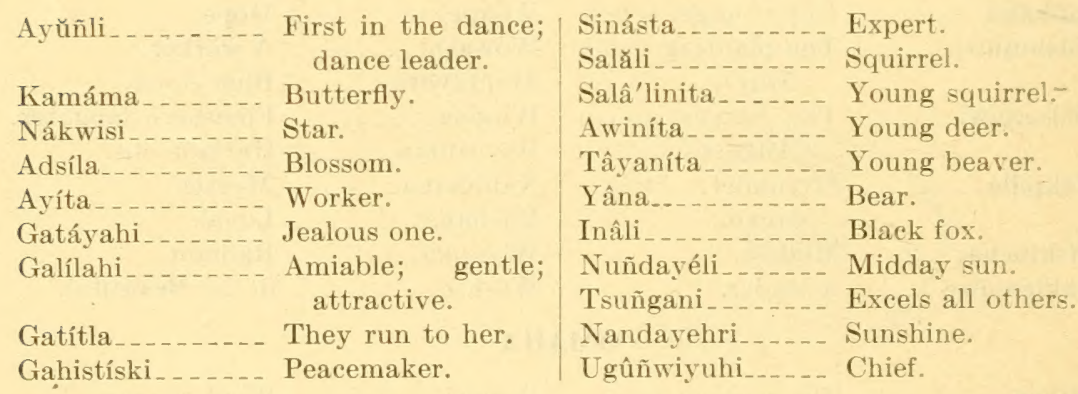




\section{SENECA}

Deweñ'doñs

Gaoñya'was

Gaji'jens

Gahadi'yas

Ganoñwi'yas

Saiyen'gu

Yaneñowi

Goñwasgoñ'gwen
It swings.

It shakes the sky.

Its flowers fall.

It crosses the forest. It crosses the swamp.

Lost again in mist. She guards the corn. She took one from the water.

\section{CHIPPEWA OJIBWA)}

Swangideed Brave, courageous.

Memengwa ....... Butterfly.

Chamaniked _. . . Canoe maker.

Ogima_........... Chief.

Ogimâwiwin _. . . C Chieftainship.

Nâmid _.......... Dancer.

Odânisima _...... Daughter.

Bidâban......... It begins to dawn.

Enâbandang _... . Dreamer.

Migisi_....... . . Eagle.

Wâbanang

Inawendiwin

Nitagewinin

Makisinikewinini .

Wâwinges

Wâbaningosi

Anâng

Songitehe.
Along the hillside. Nothing but flowers.

Moving flowers.

Early day.

It awakens them. It drags the forest. She is alert.

\section{TAOS}

Ancháli _._._. . . Painter.

Hlátsíwana

Great eagle.

Kwólana kúvui _. Handsome girl.

\section{ALGONQUIAN}

Soketao _....... Strong hearted.

Meyotao_....... True hearted.

Kwamestowa

(abbr.) _....... Guardian.

Kitei

Assiningwe
Great.

Stone face.

\section{ARAPAHO}

Hanhananank _- White wolf.

\section{CAMP NAMES}

\section{CHEROKEE}

Adáhi

In the woods; forest place.

Taláhi

In the oaks; oak forest.

Natsíhi

In the pines.

Tsiskwáhi

Bird place.

Amaiyúlti

Waterside; near the water.

Tahígwa

At peace.

Salúyi.

In the thicket.

Inagéi

In the wilderness.

Watuhíyi

Beautiful place.

Gatúsi

In the mountain.

Ahalúna

Lookout place.

Unalíyi.

Place of friends.

Unilawısti Council place.

Gatíyi Town house (tribal dance and council house).

Akwénasa My home. 
Amadáhi

Forest water.

Ayelíyu adáhi

In the heart (middle) of the woods.

Ǔñtalúlti

On the bank of the lake.

Elitséhi

Green meadow; verdant fields.

Ustanáli

Rock ledge.

Nŭñta udéliga

Sunset.

Yânáhi

Bear place.

Wahilíyi

Eagle place.

Kŭltsâ'te ŭñtalúlti

House by the lake.

Kŭltsâ'te adáhi

House in the woods.

\section{IROQUOIS}

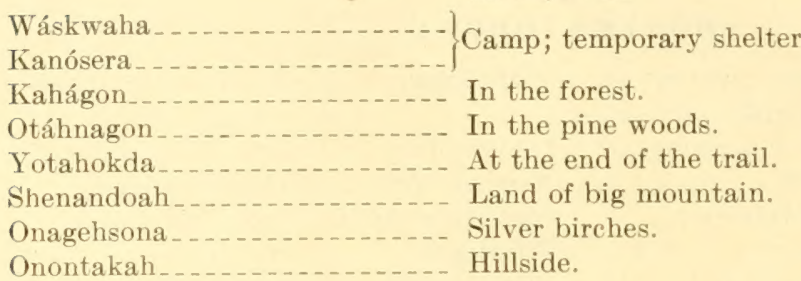

\section{CHIPPEWA}

Chickagami

By the lake.

Wasábinang Outlook; at the place of looking.

Nisátin At the foot of the mountain.

Minítik Island; one covered with trees.

Wakitátina. On the hilltop.

Anokiwáki Hunting ground.

Pikwátina Hill or mountain.

Anwébewin Rest; quietness.

Gaběshiwin, nibewin Camp.

Ningaběsh I camp.

Ogimawigamig In the chief's lodge.

Nawakwa. In the middle of the forest.

Chigakwa Near the forest.

Wigiwam Lodge.

Wanagekogamig Lodge of cedar bark.

Wigwasiwigamig Lodge of bireh bark.

Wakaigan Log house.

Manakiki Maple forest.

Ininatig Maple tree.

Miskwawak Red cedar.

Mishkwawakokang In a place where there are red cedars.

Agaming On the shore.

Mitigwaki Woods (forest).

Mitigwaking. In the woods.

Nopiming In a forest.

Wayekwamok At the end of the trail.

Teikadin Hillside.

Wigwassan. Silver birches.

Wigwass Birch (tree).

Ningabianiganig Sunset lodge.

Ningabianong Sunset point.

Tekene Dark forest.

Bimakwa Thick woods. 


\section{EASTERN ALGONQUIAN}

Sipsis

Little river or brook.

Odina

Mountain.

Wadjiw

Mountain.

\section{DELAWARE}

Wappacomo

Wanamingo

Land of white fog.

Talala paseying Place of red clay.

Paseying Cedar valley.

Wikwamis Valley.

Wasigan Small lodge. Sunset.

\section{ALGONKIN}

Wayekwakana At the end of the trail.

Chebegamig Haunted place.

\section{MISCELLANEOUS CAMP AND CLUB NAMES}

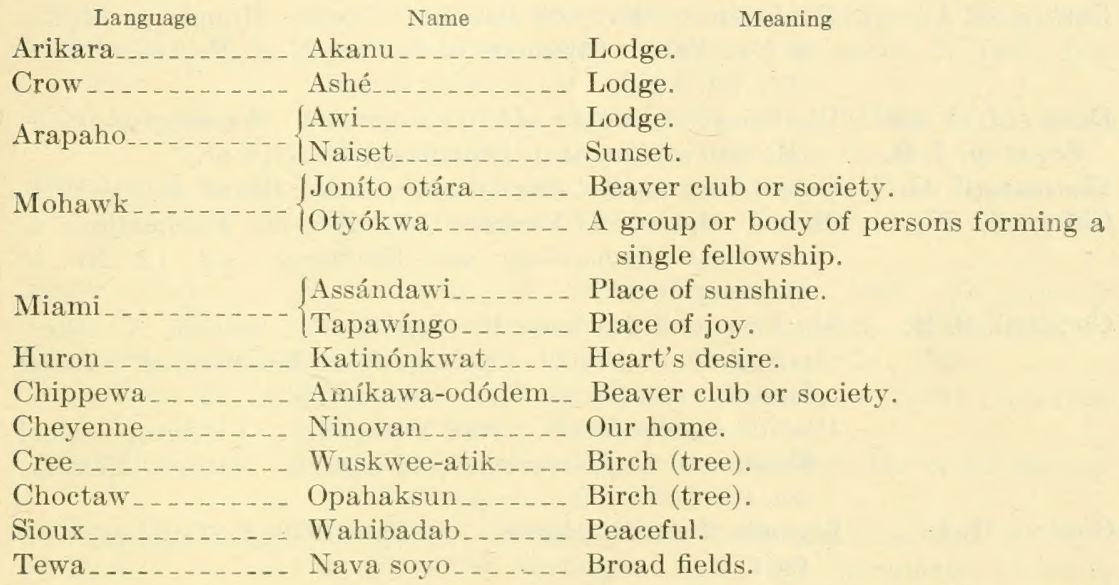

The bureau is also in constant receipt of requests for titles of books on Indian folk tales and myths. To meet this demand the following list of a few of the published writings on the subject is given:

\section{BOOKS ON FOLK-LORE, MYTHS, AND LEGENDS}

Barrett, S. A _... Myths of the Southern Sierra Miwok. (University of California Publications in American Archaeology and Ethnology, vol. 16, No. 1, 1919, Berkeley.)

Boas, Franz _.... Tsimshian Mythology. Washington, 1916. (Thirty-first Annual Report of the Bureau of American Ethnology.)

Canfield, W. W _. Legends of the Iroquois. New York, A. Wessels Co., 1902. Chapman, J. W _._- Tenia Texts and Tales from Anvik, Alaska, with vocabulary by P. E. Goddard. Leyden, Holland, E. J. Brill, 1914. (Publications of the American Ethnological Society of New York, vol. 6.) 
Chicago Folk- The Folk-Lorist, vol. 1, No.1. Chicago, the Chicago Folk -

\section{Lore Society.}

Compton, M

Curtin, J

Hewitt, J. N.

B., Comps.

Curtis, E. S

Cushing, F. H - :

Dixon, R. B Lore Society, 1892

The American Indian Fairy Tales. New York, Dodd, Mead \& Co., 1907.

Myths of the Modoes. Boston, Little, Brown \& Co., 1912.

Creation Myths of Primitive America. Boston, Little, Brown \& Co., 1898.

Seneca Indian Myths. New York, E. P. Dutton \& Co., 1923.

Seneca Fiction, Legends and Myths. Washington, 1918. (Thirty-second Annual Report of the Bureau of American Ethnologv.)

The North American Indian. New York, 1907-1922. (The 12 volumes of this work thus far published may be consulted in the more important libraries.)

Outlines of Zuñi Creation Myths. Washington, 1896. (Thirteenth Annual Report of the Bureau of Ethnology.) Zuñi Folk Tales. New York, G. P. Putnam's Sons, 1901.

Maidu Texts. Leyden, Holland, E. J. Brill, 1912. (Publications of the American Ethnological Society of New York, vol. 4.)

Dorsey, G. A..... Traditions of the Skidi Pawnee. Boston, Houghton, Mifflin \& Co., 1904. (Memoirs of the American Folk-Lore Society, vol. 8.)

Dorsey, J. O., and Dictionary of Biloxi and Ofo Languages. Washington, 1912. Swanton, J. R.

Eastman, E. G. Gifford, E. W. (Bureau of American Ethnology, Bulletin 47.)

Indian Legends Retold. Boston, Little, Brown \& Co., 1919. Miwok Myths. (University of California Publications in Ameriean Archaeology and Ethnology, vol. 12, No. 8, Berkeley, 1917.)

Goddard, P. E... Myths and Tales from the San Carlos Apache. (Anthropological Papers of the American Museum of Natural History, vol. 24, pt. 1, New York, 1918.)

Jicarilla Apache Texts. New York, 1911. (Anthropological Papers of the American Museum of Natural History, vol. 8.)

Gordon, H. L _... Legends of the Northwest. St. Paul Book \& Stationery Co., 1881.

Grinnell, G. B _._. Blackfoot Lodge Tales. New York, C. Scribner's Sons, 1892.

Pawnee Hero Stories and Folk-tales. New York, Forest and Stream Publishing Co., 1889.

Punishment of the Stingy and other Indian Stories. New York, Harper \& Brothers, 1901.

Hewitt, J. N. B.-- Iroquoian Cosmology. Washington, 1904. (Twenty-first Annual Report of the Bureau of American Ethnology.)

Hopkins, W. J_..- The Indian Book. Boston, Houghton, Mifflin \& Co., 1911. Judd, M. C_. . . . Wigwam Stories. Boston, Ginn \& Co., 1901.

Judson, K. B _... Myths and Legends of California and the Old Southwest. Chicago, A. C. McClurg \& Co., 1912.

Myths and Legends of the Pacific Northwest. Chicago, A. C. McClurg \& Co., 1912.

Myths and Legends of Alaska. Chicago, A. C. McClurg \& Co., 1911. 
Judson, K. B .... Myths and Legends of the Mississippi Valley: and the Great Lakes. Chicago, A. C. McClurg \& Co., 1914.

Old Crow and His Friends. Animal adventures based upon Indian myths. Boston, Little, Brown \& Co., 1918.

Myths and Legends of British North America. Chicago, A. C. MeClurg \& Co., 1917.

Old Crow Stories. Boston, Little, Brown \& Co., 1917.

Leland, C. G.... Algonquin Legends of New England. Boston, Houghton, Mifflin \& Co., 1884.

Leland, C. G., and Kulóskap the Master. New York, Funk \& Wagnalls Co., Prince, J. D.

Lloyd, W. J 1902.

Aw-aw-tam Indian Nights. Westfield, N. J., The Lloyd Group, 1911.

Lowie, R. H_.... Myths and Traditions of the Crow Indians. (Anthropological Papers of the Ameriean Museum of Natural History, vol. 25, pt. 1. New York, 1918.

Lummis, C. F _... Pueblo Indian Folk-Stories. Illustrated by G. W. Edwards. New York, The Century Co., 1916.

Man Who Married the Moon. New York, The Century Co. $[1902]$.

New Mexico David. New York, C. Scribner's Sons, 1891.

McLaughlin, M. L. Myths and Legends of the Sioux. Bismarck, N. Dak., Bis-

(Mrs.).

Matthews, W_... Navaho Legends. Boston, Houghton, Mifflin \& Co., 1897. (Memoirs of the American Folk-Lore Society, vol. 5.)

Merriam, C. Hart. Dawn of the World. Myths and Weird Tales told by the Mewan Indians of California. Cleveland, A. C. Clark Co., 1910.

Mooney, James_.. Myths of the Cherokee. Washington, 1902. (Nineteenth Annual Report of the Bureau of American Ethnology.)

North American Indian Fairy Tales. = London, Gibbings \& Co., 1905.

Owen, Mary A _... Folk-Lore of the Musquakie Indians of North America. London, David Nutt, 1904.

Parker, A. C _... Seneca Myths and Folk Tales. (Buffalo Historical Society Publications, vol. 27, 1923.)

Phillips, W. S_..._ Totem Tales. Chicago, Star Publishing Co., 1896.

Rand, S. T _.._Legends of the Micmacs. New York, Longmans, Green \& Co., 1894.

Pink, H........ Tales and Traditions of the Eskimo. Edinburgh, Wm. Blackwood \& Sons, 1875.

Schoolcraft, H. R_ Indian Fairy Book. From the original legends, with 8 illustrations in color by Florence Choate and Elizabeth Curtis. New York, F. A. Stokes Co., 1916.

Schultz, J. W _... . Blackfeet Tales of Glacier National Park. Boston, Houghton, Mifflin \& Co., 1916.

Simms, S. C_.... Traditions of the Crow. Chicago, 1903. (Field Museum of Natural History, Anthropological Series, vol. 2, No.6.)

Smith, B. H..... Yosemite Legends. San Francisco, P. Elder \& Co., 1904.

Smith, E. A _._. Myths of the Iroquois. Washington, 1883. (Second Annual Report of the Bureau of Ethnology.)

Spence, L._..... Myths of the North American Indians. London, G. G. Harrap \& Co., 1914. 
Stevenson, M. C_- Zuñi Indians, Their Mythology, Esoteric Fraternities and Ceremonies. Washington, 1905. (Twenty-third Annual Report of the Bureau of American Ethnology.)

Swanton, J. R _..- Tlingit Myths and Texts. Washington, 1909. (Bureau of American Ethnology, Bulletin 39.)

Wilson, F. N _...- Indian Hero Tales. New York, American Book Co,, 1916.

Wilson, G. L _.... Myths of the Red Children. Boston, Ginn \& Co., 1907.

Young, E. R _.... Algonquin Indian Tales. New York, Eaton \& Mains, 1903.

Zitkla-Sä _....... Old Indian Legends. Boston, Ginn \& Co., 1904.

Consult also the Journal of American Folk-Lore, 1888-1914, Boston and New York, Houghton, Mifflin \& Co.

Washington, D. C., October, 1926. 



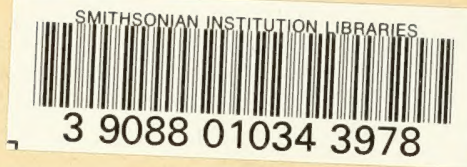

